\title{
Parental smoking related to adenoidectomy and tonsillectomy in children
}

\author{
G. SAID \\ From Bagneux, Paris, France \\ J. ZALOKAR, J. LELlOUCH, AND E. PATOIS \\ From Unité de Recherches Statistiques, INSERM, Villejuif, France
}

SUMMARY Histories of adenoïdectomy and tonsillectomy were ascertained, as well as smoking habits of both parents, using questionnaires answered by 3920 schoolchildren aged 10 to 20 . Adenoïdectomy and/or tonsillectomy, considered as an index of repeated upper respiratory tract disease in early childhood, was very significantly related to the amount of smoking by each parent. This relationship persisted when age, sex, day nursery attendance, sibship size, and history of appendicectomy were controlled.

\section{Introduction}

An association between respiratory symptoms in children and the smoking habits of their parents has been found in several studies. Colley (1974) showed that the prevalence of cough in schoolchildren aged 6 to 14 was related to smoking by their parents. This relationship appeared to be indirect and cross-infection was an important element, as the prevalence was doubled among children whose parents had respiratory symptoms not associated with smoking. Colley et al. (1974) also found that the incidence of bronchitis and pneumonia among infants under one year of age was doubled when both parents smoked, whether or not the parents also had respiratory symptoms. Over the age of one year, the incidence was related only to parental respiratory symptoms.

Recently Lebowitz and Burrows (1976) have reported that persistent cough, phlegm, and wheezing in children under 15 were related to smoking habits of adults in their households, but not significantly so when similar respiratory symptoms in household adults were controlled. Harlap and Davies (1974) studied hospital admission rates during the first year of life of infants whose mothers' smoking habits were known. The babies of smoking mothers were more often admitted for bronchitis and pneumonia, but there was no significant difference in admission rates for upper respiratory tract infections. This negative result is in contrast with experimental findings that in animals placed in a smoke-filled atmosphere, a large proportion of smoke particles are retained in the upper respiratory tract (Chretien et al., 1973). However, as Harlap and Davies (1974) remarked, hospital admission rates are a poor indicator of the incidence of upper respiratory tract infections, which rarely require hospital treatment.

We present here the results of an investigation of the relationship between adenoidectomy and/or tonsillectomy in children, selected as an index of upper respiratory tract disease, and smoking by their parents.

\section{Methods}

Although the prevalence of upper respiratory tract disease is difficult to estimate directly, the child with repeated attacks is often, rightly or wrongly, subjected to adenordectomy at about one year of age, and/or tonsillectomy at about five years of age. For this reason, we chose history of adenoidectomy and/or tonsillectomy (A or $\mathrm{T}$ ) as an index of the prevalence of upper respiratory tract disease. Since these operations occur in early childhood, they precede any smoking by the child himself.

In 1975-76, students in nine secondary schools in Paris were given questionnaires to fill in by themselves in class. The questions covered sex; age; number of siblings; day nursery attendance before the age of three; smoking habits of mother (choices: non-smoker, 1 to 5,6 to 10,11 to 20 , or more than 20 cigarettes a day) and father (choices: the same + pipe or cigars); and history of adenoidectomy, tonsillectomy, and appendicectomy. This last was 
Table 1 Percentages (total numbers) of children reporting adenoidectomy and/or tonsillectomy by amount of smoking by each parent, as reported by their children

\begin{tabular}{|c|c|c|c|c|c|c|c|}
\hline \multicolumn{8}{|c|}{ FATHERS } \\
\hline & \multirow[b]{2}{*}{ Non-smokers } & \multicolumn{4}{|c|}{ No. of cigarettes a day } & \multirow{2}{*}{$\begin{array}{l}\text { Pipe and } \\
\text { cigar only }\end{array}$} & \multirow{2}{*}{$\begin{array}{l}\text { ALL } \\
\text { FATHERS }\end{array}$} \\
\hline & & $1-5$ & $6-10$ & $1 I-20$ & $21+$ & & \\
\hline \multicolumn{8}{|l|}{ MOTHERS } \\
\hline Non-smokers & $\begin{array}{c}28 \\
(1550)\end{array}$ & $\begin{array}{c}37 \\
(412)\end{array}$ & $\begin{array}{c}39 \\
(380)\end{array}$ & $\begin{array}{c}48 \\
(305)\end{array}$ & $\begin{array}{c}54 \\
(175)\end{array}$ & $\begin{array}{c}31 \\
(157)\end{array}$ & $\begin{array}{c}35 \\
(2979)\end{array}$ \\
\hline \multicolumn{8}{|c|}{ Cigarettes a day } \\
\hline $1-5$ & $\begin{array}{c}37 \\
(110)\end{array}$ & $\begin{array}{r}44 \\
(123)\end{array}$ & $\begin{array}{c}48 \\
(87)\end{array}$ & $\begin{array}{r}56 \\
(62)\end{array}$ & $\begin{array}{c}50 \\
(42)\end{array}$ & $\begin{array}{c}43 \\
(58)\end{array}$ & $\begin{array}{r}45 \\
(482)\end{array}$ \\
\hline $6-10$ & $\begin{array}{c}38 \\
(74)\end{array}$ & $\begin{array}{c}50 \\
(34)\end{array}$ & $\begin{array}{c}60 \\
(83)\end{array}$ & $\begin{array}{c}39 \\
(38)\end{array}$ & $\begin{array}{c}53 \\
(19)\end{array}$ & $\begin{array}{c}56 \\
(18)\end{array}$ & $\begin{array}{r}49 \\
(266)\end{array}$ \\
\hline $11+$ & $\begin{array}{c}51 \\
(55)\end{array}$ & $\begin{array}{l}47 \\
(15)\end{array}$ & $\begin{array}{c}58 \\
(12)\end{array}$ & $\begin{array}{c}67 \\
(45)\end{array}$ & $\begin{array}{c}48 \\
(40)\end{array}$ & $\begin{array}{c}58 \\
(26)\end{array}$ & $\begin{array}{r}552 \\
(193)\end{array}$ \\
\hline ALL MOTHL & 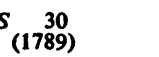 & $\begin{array}{c}40 \\
(584)\end{array}$ & $\begin{array}{r}44 \\
(562)\end{array}$ & $\begin{array}{c}50 \\
(450)\end{array}$ & $\begin{array}{c}53 \\
(276)\end{array}$ & $\begin{array}{r}381 \\
(259)\end{array}$ & $\begin{array}{r}38 \\
(3920)\end{array}$ \\
\hline
\end{tabular}

1 Test of significance of difference in $\% A$ or $T$ by amount of smoking of fathers : $\chi^{2}=118 \cdot 0,5 \mathrm{DF}, \mathrm{P}<\cdot 001$

2 Test of significance of difference in $\% \mathrm{~A}$ or $\mathrm{T}$ by amount of smoking of mothers $: \chi^{2}=63 \cdot 0,3 \mathrm{DF}, \mathrm{P}<\cdot 001$

intended as a control question. The children were not informed of the purpose of the questionnaire.

Less than $1 \%$ of the questionnaires lacked information on parents' smoking habits or on history of operations and these were rejected. The questionnaires of 3920 students $(35.9 \%$ boys and $64 \cdot 1 \%$ girls) aged 10 to 20 (except for 35 under the age of 10) were finally analysed. Information on number of siblings or sex was missing on 52 questionnaires $(1 \cdot 3 \%)$.

Very few children (56) reported that their mothers smoked more than 20 cigarettes a day, so they were grouped with those reporting maternal smoking of 11 to 20 cigarettes a day. Children whose fathers were reported to smoke both cigarettes and a pipe or cigars were grouped by paternal cigarette consumption, leaving a residual category of children whose fathers smoked a pipe or cigars only. The results were analysed using the $x^{2}$ test with Yates' correction where appropriate.

\section{Results}

Table 1 shows the percentage of children reporting A or T, or both, grouped by the smoking habits of each parent. In the lower section of the Table it can be seen that the percentage of $A$ or $T$ increased very markedly with the quantity of cigarettes smoked by the mother, and very significantly also with the number smoked by the father. There is an intermediate value for the group whose fathers smoked a pipe or cigars only.
Table 2 Percentages (total numbers) of children reporting adenoidectomy and/or tonsillectomy by age and sex

\begin{tabular}{lccc}
\hline Age & Boys & Girls & Total by age \\
\hline$<15$ & 40 & 36 & 37 \\
$15+$ & $(633)$ & $(1308)$ & $(1941)$ \\
& 44 & 35 & 38 \\
Total by sex & $(766)$ & $(1196)$ & $(1962)$ \\
& 42 & 36 & \\
\hline
\end{tabular}

Difference between boys and girls significant at $0.1 \%$ level. Difference between ages not significant overall or for either sex.

If the smoking habits of both parents are considered simultaneously, the frequency of A or T was higher when both parents smoked than when only one did, except when one parent was a heavy smoker. Thus, while $28 \%$ of the children with two non-smoking parents reported a history of A or T, calculations summarising Table 1 show that $42 \%$ of the children with one smoking parent, and $51 \%$ of the children with two smoking parents, reported such a history.

Boys reported A or T more frequently than girls (Table 2). Age differences were not significant. Children who had attended a day nursery also reported $\mathrm{A}$ or $\mathbf{T}$ more frequently than non- $\sigma$ attenders (47\% compared with $37 \%)$. The percentage N of children reporting $A$ or $T$ decreased regularly overall from $47 \%$ of only children to $29 \%$ of those with three or more siblings (Table 3), but considered separately by sex and number of smoking parents (both these variables interact with family size), 
there was no general drop in percentage $A$ or $T$ until family size reached two or more siblings. Nevertheless, the strong relationship between parental smoking and history of $\mathrm{A}$ or $\mathrm{T}$ was found in both sexes and in all sibship sizes, irrespective of day nursery attendance, and in eight of the nine schools, drawing pupils from a variety of socioeconomic strata. The association was not significant in the ninth school, where only 36 children took part.

A significant association was found between amount of maternal (but not paternal) smoking and percentage of appendicectomies (Table 4, totals). This was mainly due to the increased frequency of appendicectomy in children with a history of $\mathbf{A}$ or $\mathbf{T}$ $(25 \%)$ compared to those without such a history $(16 \%)$. But a weak association did remain between appendicectomies and amount of maternal smoking among children without a history of $A$ or $T$. Appendicectomies were reported significantly more often in girls $(20 \%)$ than boys $(18 \%)$ but the slightly higher proportion of older children reporting this operation was only marginally significant and there was no relationship to number of siblings.

\section{Discussion}

Our study confirms the finding of an association between parental smoking and the prevalence of persistent upper respiratory tract disease in their children, as indicated by adenoidectomy or tonsillectomy. However, some points need further elucidation.

First, how valid are reports by those aged 10 to 20 of operations that may have occurred in the first few years of life? As a rule, children are aware of their past operations, partly because of the importance attached to these by their parents, and partly because of the many medical forms they will have filled in at school. The overall proportion reporting A or $T$ $(38 \%)$ seems to correspond to medical practice in the early 1960 s. We note that the reporting of day nursery attendance, another event occurring before three years of age, followed the expected demographic pattern: it was most often reported among only children, and least often among those with three or more siblings.

The proportion (19\%) reporting appendicectomy may appear surprisingly high in comparison with that

Table 3 Percentages (total numbers) of children reporting adenoidectomy and/or tonsillectomy by sex, number of siblings, and smoking habits of parents as reported by their children

\begin{tabular}{|c|c|c|c|c|c|c|c|c|c|}
\hline \multirow{2}{*}{$\begin{array}{l}\text { No. of } \\
\text { siblings }\end{array}$} & \multicolumn{3}{|l|}{ Boys } & \multicolumn{3}{|l|}{ Girls } & \multirow{2}{*}{ Total } & \multicolumn{2}{|c|}{ Test of significance* } \\
\hline & \multicolumn{3}{|c|}{$\begin{array}{l}\text { No. of smoking parents } \\
0\end{array}$} & \multicolumn{3}{|c|}{${ }_{0}^{\text {No. of smoking parents }}{ }_{2}$} & & Boys & Girls \\
\hline $\begin{array}{l}2 \\
3+\end{array}$ & $\begin{array}{c}29 \\
(69) \\
38 \\
(180) \\
34 \\
(144) \\
25 \\
(162)\end{array}$ & $\begin{array}{c}55 \\
(96) \\
56 \\
(151) \\
44 \\
(145) \\
33 \\
(180)\end{array}$ & $\begin{array}{c}75 \\
(36) \\
52 \\
(93) \\
55 \\
(64) \\
53 \\
(62)\end{array}$ & $\begin{array}{c}34 \\
(97) \\
32 \\
(280) \\
27 \\
(237) \\
18 \\
(353)\end{array}$ & $\begin{array}{c}51 \\
(120) \\
44 \\
(248) \\
39 \\
(284) \\
33 \\
(428)\end{array}$ & $\begin{array}{c}57 \\
(46) \\
56 \\
(135) \\
50 \\
(103) \\
37 \\
(155)\end{array}$ & $\begin{array}{r}47 \\
(464) \\
44 \\
(1087) \\
38 \\
(977) \\
29 \\
(1340)\end{array}$ & 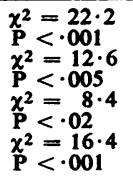 & 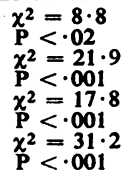 \\
\hline Total & $\begin{array}{r}32 \\
(555)\end{array}$ & $\begin{array}{r}46 \\
(572)\end{array}$ & $\begin{array}{c}56 \\
(255)\end{array}$ & $\begin{array}{c}26 \\
(967)\end{array}$ & $\begin{array}{c}39 \\
(1080)\end{array}$ & $\begin{array}{c}48 \\
(439)\end{array}$ & & 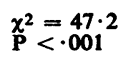 & $\begin{array}{l}\chi^{2}=76 \cdot 0 \\
\mathrm{P}<\cdot 001\end{array}$ \\
\hline
\end{tabular}

*Test of significance of difference in $\% \mathrm{~A}$ or $\mathrm{T}$ by number of smoking parents : $\chi^{2}$ with $2 \mathrm{DF}$

Table 4 Percentages (total numbers) of children reporting appendicectomy by amount of smoking of each parent and by whether or not they also reported $A$ or $T$

\begin{tabular}{|c|c|c|c|c|c|c|c|}
\hline \multirow[b]{2}{*}{ A or $T$} & \multirow{2}{*}{$\begin{array}{l}\text { Mothers } \\
\text { Non-smoker }\end{array}$} & \multicolumn{3}{|c|}{ No. of cigarettes a day } & \multirow{2}{*}{\multicolumn{2}{|c|}{ Test of significance }} & \\
\hline & & $1-5$ & $6-10$ & $11+$ & & & \\
\hline $\begin{array}{l}\text { No } \\
\text { Yes }\end{array}$ & $\begin{array}{c}15 \\
(1951) \\
24 \\
(1028)\end{array}$ & $\begin{array}{c}17 \\
(264) \\
23 \\
(218)\end{array}$ & $\begin{array}{c}21 \\
(136) \\
25 \\
(130)\end{array}$ & $\begin{array}{c}24 \\
(87) \\
36 \\
(106)\end{array}$ & $\begin{array}{l}x^{2}= \\
\mathrm{P}< \\
x^{2}= \\
\mathrm{P}<\end{array}$ & & \\
\hline \multirow[t]{2}{*}{ Total } & $\begin{array}{c}18 \\
(2979)\end{array}$ & $\begin{array}{r}20 \\
(482)\end{array}$ & $\begin{array}{c}23 \\
(266)\end{array}$ & $\begin{array}{r}31 \\
(193)\end{array}$ & $\begin{array}{l}x^{2}= \\
P\end{array}<\cdot$ & & \\
\hline & Fathers & \multicolumn{4}{|c|}{ No. of cigarettes a day } & & \\
\hline$A$ or $T$ & Non-smoker & $1-5$ & $6-10$ & $11-20$ & $2 I+$ & Pipe or & Test of significance \\
\hline $\begin{array}{l}\text { No } \\
\text { Yes }\end{array}$ & $\begin{array}{r}17 \\
(1259) \\
23 \\
(530)\end{array}$ & $\begin{array}{c}13 \\
(352) \\
24 \\
(232)\end{array}$ & $\begin{array}{c}15 \\
(313) \\
28 \\
(249)\end{array}$ & $\begin{array}{c}18 \\
(223) \\
28 \\
(227)\end{array}$ & $\begin{array}{r}20 \\
(131) \\
26 \\
(145)\end{array}$ & $\begin{array}{l}12 \\
(160) \\
22 \\
(99)\end{array}$ & $\begin{array}{l}x^{2}=7 \cdot 2 \\
P>\cdot 20 \\
\chi^{2}=3 \cdot 7 \\
P>\cdot 50\end{array}$ \\
\hline Total & $\begin{array}{r}19 \\
(1789)\end{array}$ & $\begin{array}{c}17 \\
(584)\end{array}$ & $\begin{array}{c}20 \\
(562)\end{array}$ & $\begin{array}{c}23 \\
(450)\end{array}$ & $\begin{array}{c}23 \\
(276)\end{array}$ & $\begin{array}{c}16 \\
(259)\end{array}$ & 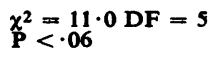 \\
\hline
\end{tabular}


in English-speaking countries. In French medical practice, appendicectomy can be considered as an index of the incidence of acute abdominal conditions rather than appendicitis. In fact, since all doubtful cases are resolved in favour of appendicectomy, a perforated appendix is rarely seen here. The fact that more girls than boys reported appendicectomy accords with the preponderance of girls among older children with recurrent abdominal pain (Dodge, 1976).

The strong association between history of $\mathrm{A}$ or $\mathrm{T}$ and appendicectomy may have been due to several factors. There is, firstly, the possibility that some children answered positively (or negatively) to all three questions about operations; but the fact that appendicectomies showed a different demographic pattern than $A$ or $T$ tends to increase confidence in the validity of the self-reporting of operations by these schoolchildren. Then there is the positive association between social class and number of elective operations that has been found in the United States and Europe (Roos et al., 1977; Wingerd and Sponzilli, 1977). Furthermore, independent of social class, there may be 'operation prone' children, at the mercy of their parents' or family doctors' predilections. On the other hand, some proportion of children presenting with acute abdominal conditions do in fact have upper respiratory infections (British Medical Journal, 1976; Dodge, 1976; Jones, 1976).

Secondly, how valid is information about parental smoking provided by those aged 10 to 20 , and how are present smoking habits related to those of perhaps 15 years ago at the time of the $A$ or $T$ ? The proportions of children reporting both parents non-smokers $(40 \%)$, one parent smoking $(42 \%)$, and both parents smoking $(18 \%)$ were consistently the same for both sexes and for all age groups. Compared with a study of Paris policemen aged 46 to 52 (Zalokar et al., 1974), less smoking by fathers was reported, but compared with a study of pregnant women in Paris (Schwartz et al., 1972), more smoking by mothers was reported. Smoking by men in France is negatively related to social class and the proportion of men who stop smoking increases after the age of 45. By contrast, smoking by pregnant women is positively related to social class. Judging from the present study, maternal smoking may increase with age. It must be noted, however, that changes in parental smoking habits after the epoch of $\mathbf{A}$ or $\mathrm{T}$ would lead to an underestimation of the relationship of these variables.

More seriously, it is possible that the children who reported $\mathbf{A}$ or $\mathbf{T}$ or appendicectomy were more inclined to over-report parental smoking in spite of not knowing the purpose of the questionnaire.
(Bias can also occur in the opposite direction when parents are asked about their own smoking habits in conjunction with their children's symptoms). This was the reason for our question about appendicectomy; we thought $a$ priori that it would not be associated with parental smoking.

However, the weaker association between maternal smoking and appendicectomy, even if it is due to this type of bias, cannot explain the much stronger association between $\mathrm{A}$ or $\mathrm{T}$ and parental smoking which remained among children not reporting appendicectomy. The most likely explanation for the association of appendicectomy with maternal smoking is that both increase with the rising socioeconomic status of the family. Also, since appendicectomy is generally performed at a later age than $A$ or $T$, it may be more closely related to present maternal smoking habits.

Even so, social class cannot be considered an important intervening variable in the relationship between parental smoking and A or T, since, as we have noted above, the social class gradients of smoking habits for men and women in France tend to run in opposite directions, yet the smoking habits of each parent are very significantly related to $A$ or $\mathbf{T}$ in their children.

Reprints from J. Zalokar, U. 169, Institut Nationat. $\overrightarrow{0}$ de la Santé et de la Recherche Médicale, 16 biš Avenue Paul Vaillant-Couturier, 94800 Villejuif, France.

\section{References}

British Medical Journal (1976). Editorial: Children with appendicitis. British Medical Journal,2, 440-441.

Chretien, J., Hirsch, A., and Thieblement, M. (1973). Pathologie Respiratoire $d u$ Tabac, p. 36. Masson: Paris.

Colley, J. R. T. (1974). Respiratory symptoms and parental smoking and phlegm production. British Medical Journal, 2, 201-204.

Colley, J. R. T., Holland, W. W., and Corkhill, R. T. (1974). Influence of passive smoking and parental phlegm on pneumonia and bronchitis in early childhood. Lancet, 2, 1031-1034.

Dodge, J. A. (1976). Problems of childhood: recurrent abdominal pain in children. British Medical Journal, 1, 385-389.

Harlap, S., and Davies, A. M. (1974). Infant admission to hospital and maternal smoking. Lancet, 1, 529-532.

Jones, P. F. (1976). Active observation in management of acute abdominal pain in childhood. British Medical Journal, 2, 551-553.

Lebowitz, M. D., and Burrows, B. (1976). Respiratory symptoms related to habits of family adults. Chest, 69, 48-50. 
Roos, N. P., Roos, L. L. Jr., Henteleff, P. D. (1977). Wingerd, J., and Sponzilli, E. E. (1977). Concentrations Elective surgery rates-do high rates mean low of serum protein fractions in white women: effects of standards? New England Journal of Medicine, 297, 360-365.

Schwartz, D., Goujard, J., Kaminski, M., and Rumeau-Rouquette, C. (1972). Smoking and pregnancy. Results of a prospective study of 6989 women. Revue Européenne d'Etudes Cliniques et age, weight, smoking, tonsillectomy, and other factors. Clinical Chemistry, 23, 1310-1317.

Zalokar, J., Lellouch, J., Claude, J. R., and Kuntz, D. (1974). Epidemiology of serum uric acid and gout in Frenchmen. Journal of Chronic Diseases, 27, 59-75.

Biologiques, 17, 867-879. 